\title{
TOWARDS MEASUREMENT OF POLITICAL PRESSURE ON CENTRAL BANKS: THE CASE OF THE CENTRAL BANK OF EGYPT
}

\author{
Ibrahim L. Awad*
}

\begin{abstract}
:
This paper assesses whether the legal independence granted to the Central Bank of Egypt (CBE) by the latest legislation promulgated in 2005 is factual. The author followed Fry's methodology, which assumes that the level of independence of the central bank is determined by fiscal attributes. In an attempt to develop Fry's method, there was used a simple criterion to assess the central bank's independence, namely, that the central bank is actually independent if it can fulfill its money supply target without squeezing the private sector. Applying this criterion to the case of the CBE, we find that the legal independence granted to the CBE by the latest legislation is not factual.
\end{abstract}

Keywords: central bank independence; fiscal dominance; political pressure

JEL Classification: E51, E59, H75, C23

\section{Introduction}

With the problem of higher inflation facing the industrialized economies during the 1970s and early 1980s, one important argument pointed to an inherent inflation bias in discretionary monetary policy. Under rational expectations an expansionary monetary policy will not affect real output, but average inflation will be higher. This explanation raises the question 'Why might central banks prefer economic expansions or have output goals that exceed the natural rate of output?' Economists frequently point to political pressures on the central bank (CB). Numerous studies have tried to measure politicians' influence on monetary policymakers. The fundamental assumption of these studies is that the $\mathrm{CB}$ is more concerned than the elected government with maintaining low and stable rates of inflation. Consequently, if the CB became less subject to political pressure it would be able to deliver lower rates of inflation.

One branch of these studies has tried to measure central bank independence (CBI) by constructing indices for $\mathrm{CBI}$ derived from $\mathrm{CBs}$ ' charters and estimating the relationship between such indices and the rate of inflation. The major defect of these studies is that legal indices may not reflect the relationship between governments and CBs that exists in reality. In countries with a lower degree of democracy and where the rule of law is less strongly embedded in the political culture, as in most developing countries, there can be

* Faculty of Social Sciences, Charles University in Prague (ibrahim@fsv.cuni.cz). 
a wide gap between the formal legal institutional arrangements and the actual practice. Thus, for developing countries, these CBI indices may not be accurate, because legal independence does not mean actual independence.

"Actual independence is impossible to quantify" (Cukierman, 1992, p. 273). Another branch of these studies did not take Cukierman's advice and tried to measure the actual independence of CBs using some indicators of political pressure. The central tenet of this approach is that political pressure on the $\mathrm{CB}$ will arise even if the $\mathrm{CB}$ is legally independent. Politicians always try to influence the $\mathrm{CB}$ to adopt policies compatible with their preferences. The degree of responsiveness of the $\mathrm{CB}$ to such political pressure depends on the extent to which the CB is actually independent. Then, by constructing an indicator of political pressure on the $\mathrm{CB}$, we can measure the degree of responsiveness of the $\mathrm{CB}$ to such political pressure and consequently judge whether $\mathrm{CB}$ independence is de facto (factual) or just de jure. The major defects of these studies are that the channels through which political pressure might work are not clear and the reaction of the $\mathrm{CB}$ to fiscal policy is ambiguous.

Furthermore, some studies give more attention to CBI in the developing countries, relying on the fiscal dominance hypothesis. In the developing countries the fiscal situation will constrain if not dictate the CB's activities and therefore determine the extent of CBI. Fry (1998) tried to measure actual CB independence by estimating the reaction of the $\mathrm{CB}$ to the government's demands to increase credit. In fact, domestic credit to the government is a crossing point between the $\mathrm{CB}$ and the government. Consequently, the reaction of the $\mathrm{CB}$ to such demands (pressure) represents a linkage between political pressure on the $\mathrm{CB}$ and the actual independence of the $\mathrm{CB}$.

In this paper I followed Fry's methodology for assessing the legal independence of CBs. I tried to develop Fry's method using a new criterion to assess the legal independence of the (CBE), namely, that the $\mathrm{CB}$ is actually independent if it can fulfill its money supply target without squeezing the private sector.

I organized this paper as follows: Section 2 presents previous studies of CBI and political pressure on CBs. Section 3 assesses the previous studies. Section 4 focuses on Fry's methodology. Section 5 focuses on our attempt to develop Fry's method. Section 6 assesses the legal independence granted to the CBE under the latest legislation. Section 7 concludes.

\section{Previous Studies of CB Independence and Political Pressure on CBs}

Greater attention has been focused on the relationship between monetary policymakers and politicians. In the literature there are two broad approaches to measuring this relationship. The first consists of studies based on legal attributes and therefore addressing the legal independence of CBs. The second involves studies based on non-legal attributes and therefore addressing political pressure on CBs. Besides these two approaches, there is another branch of studies which addresses the actual independence of CBs based on the fiscal dominance hypothesis. In this part I will briefly present each of these approaches. 


\subsection{Previous Studies of the Legal Independence of CBs ${ }^{1}$}

The theoretical basis of these studies depends on the notion that $\mathrm{CBs}$ in democratic countries are more concerned with maintaining low and stable rates of inflation than the elected government. If a $\mathrm{CB}$ becomes free of political pressure it will be able to deliver stable and low rates of inflation. In the theoretical models, CBI is introduced by means of the weight placed on inflation objectives in the loss function. The $\mathrm{CB}$ will be more independent if such weight in the loss function exceeds that of the government. The CB in this case is described as a Rogoff-conservative CB.

To measure how independent a $\mathrm{CB}$ is, empirical studies have constructed $\mathrm{CBI}$ indices based on the CB's legal characteristics. To investigate the relationship between CBI and the inflation rate, empirical studies (Eijffinger and Keulen, 1995, p. 57) have used this equation:

Average monthly inflation $(\pi)=\alpha_{0}+\alpha_{1}(\mathrm{CBI})+\varepsilon_{1}$

Using legal indices for CBI, many studies try to prove the theoretical assumption that higher levels of CBI, as detected by legal indices, will lead to lower rates of inflation. These studies have also used panel data about developing and developed countries to find such a negative correlation/relationship between CBI and the rate of inflation. Finding such a relationship is important to judge whether the legal independence of the CB is factual (de facto) or just formal (de jure).

Bade and Parkin (1977) presented the first empirical study of CBI using an index based on legal attributes. The study comprises twelve industrial countries during the period 1951-1975. They measured the independence of the CB according to the following criteria: (i) the primary objective of the $\mathrm{CB}$ according to the law; (ii) the degree of government influence over CB policy (the government's ability to appoint the members of the board of directors, government representation in the board of directors, and which authority controls monetary policy).

Alesina $(1988,1989)$ includes monetary financing rules, thus enlarging Bade and Parkin's index of policy independence to include the following criterion: the obligation of the $\mathrm{CB}$ to buy short-term treasury papers, as the monetary financing obligation can seriously harm CBI with respect to monetary policy making. Alesina (1988) examines how the degree of $\mathrm{CB}$ autonomy affects the magnitude of political influence over the economy and monetary policy. An independent $\mathrm{CB}$ is able to reduce fluctuations in monetary policy brought about by the election cycle.

Grilli, Masciandaro, and Tabellini (1991) built a two-part legal index for CBI. The authors defined "political autonomy" as the ability of the CB to select the final objectives of monetary policy, and defined "economic autonomy" as the ability of the $\mathrm{CB}$ to select monetary policy instruments. They constructed an index based on eight criteria for each part, and assigned one point for each criterion if it is satisfied ${ }^{2}$. The overall index, the total sum of the points of the two-part index, is a measurement of CBI.

1 For more details and other subsequent empirical studies, see Arnone et al. (2006a).

2 Grilli, Masciandaro, and Tabellini (GMT) (1991) define CB independence as autonomy in setting objectives and autonomy in setting instruments. But the most common terminology for defining CBI is elaborated by Debelle and Fisher (1994), who defined CBI as "goal independence" and "instrument independence." 
Cukierman (1992) constructs three indices of CBI. The first index (LVAU-LVAW) contains 16 indicators grouped under four main headings; a heading about the chief executive officer (CEO), a heading about policy formulation (PF), a heading about the objectives of the central bank (OBJ), and a heading about the limitations on the CB for lending to the government (LL). The second index, the turnover rate of the CB's governor (TOR), is based on the assumption that the higher is the TOR, the lower is the CB's autonomy. The third index (QVAU-QVAW) is constructed on the basis of responses given to a questionnaire exploring various aspects of the CB's autonomy by focusing not only on the legal aspects, but also on the instruments used by the CB.

Alesina and Summers (1993) constructed another CBI index using the average of Bade and Parkin, expanded by Alesina $(1988,1989)$ and GMT (1991).

Describing policy independence, like GMT, as the capacity of the CB to choose the final objectives of monetary policy, Eijffinger and Schaling (1993) constructed another legal index for CBI. It comprised the formal responsibility of the $\mathrm{CB}$ with regard to monetary policy, the relationship between the $\mathrm{CB}$ and the government/parliament in the formulation of monetary policy, and the procedures for the appointment of the board of directors.

Arnone et al. (2006b) presented an update of the GMT index based on the CB legislation as of the end of 2003. The index comprised a set of developing countries, emerging market economics, and OECD countries. The authors presented a reconstruction of the GMT index based on Cukierman (1992) for a smaller set of countries, and evaluated the changes in CB autonomy between 1992 and 2003. Their results point to a significant increase in $\mathrm{CB}$ autonomy particularly for developing countries. Improvements in CB autonomy had, in most cases, involved a three-stage process: an initial stage in which the political foundations for CB autonomy were laid, a stage in which operational autonomy developed, and further political autonomy in terms of policy formulation and the appointment of senior management.

Since the legal indices of CBI may not reflect the real relationship that exists in practice between the government and the $\mathrm{CB}$, another methodology (see Mahadeva and Sterne, 2000) tried to avoid this limitation by asking central bankers directly, using two methods. The first method interprets responses to the general subjective question, 'How would you define CBI?' then uses the answers to construct an index of self-assessment of CBI. The second method involves asking central bankers, 'How independent are your own institutions?' The answer to this question depends on the answers to a number of objective indicators. Using probit regression, the study attempts to explain which objective indicators of CBI explain the subjective self-assessment. One of the important results of this study is that self-assessment of CBI is strongly associated with both the degree of instrument independence measure and the absence of a deficit finance obligation. Also, the results for developing countries are similar to those of the entire sample. The absence of a deficit finance obligation and instrument independence explain the self-assessment variable. Considering the study group together with developing and transitional economies, the results show that the deficit finance limits have the most important influence on the perception of $\mathrm{CB}$ independence. 


\subsection{Previous Studies of Political Pressure on CBs}

The analysis of political pressure under this approach has been established on the background of the political business cycle. Drazen (2002) argues that reconsidering the pre-electoral political monetary cycle as an explanation for political pressure on the $\mathrm{CB}$ is important for the following reasons: (i) there may be indirect effects of the electoral cycle on monetary policy; (ii) in countries with independent central banks, pre-electoral monetary cycles are noticeable, with money growth rates rising before elections and the inflation rate rising after elections; (iii) using policy tools other than monetary policy to influence election outcomes may have a significant effect on monetary policy. The nature of this effect depends on the interaction between the $\mathrm{CB}$ and politicians.

Drazen presented a theoretical model for political pressure on the CB. Since accommodating monetary policy is worth more for politicians in election years than in non-election years, the amount of pressure differs over the electoral cycle. This induces an electoral cycle in monetary policy even though the $\mathrm{CB}$ is independent and has no electoral motive per se. In equilibrium, the monetary authority accommodates the politicians' desired policies in electoral years, but generally it is free of political influence in non-election years. An electoral cycle in fiscal policy may intensify the political monetary cycle, while an electoral structure that allows the government to call early elections may lessen it.

Empirical studies have tried to construct an indicator for political pressure on CBs. From the point of view of these studies, political pressure on CBs will occur even if the $\mathrm{CB}$ is legally independent, as politicians always try to influence the $\mathrm{CB}$ to adopt policies compatible with their preferences. But the degree of responsiveness of the $\mathrm{CB}$ to such political pressure depends on the extent to which the CB is actually independent. With a higher degree of CBI, such influence will arise only in indirect ways. So, by constructing an indicator for political pressure on the $\mathrm{CB}$ we can measure the degree of responsiveness of the $\mathrm{CB}$ to such political pressure, and consequently judge whether the independence of the $\mathrm{CB}$ is de facto or just de jure.

Havrilesky (1993) constructed an index for political pressure on CBs. This index was based on the number of newspaper reports in which politicians revealed their preferences about a more or less restrictive monetary policy. Any article calling for a monetary easing was assigned the value +1 , while any article calling for monetary tightness was assigned the value -1 . The final index, as an indicator of the net political pressure, is the net summation of the negatives and positives. Havrilesky applied his study to the Federal Reserve by counting the number of reports in the Wall Street Journal of politicians arguing in favour of more or less restrictive monetary policy. He found that the Federal Reserve's polices responded to this index.

Maier et al. (2002) applied Havrilesky's approach to the Deutsche Bundesbank after extending the analysis to include the pressure arising from other interest groups and analysing press reports in different newspapers. They concluded that the Bundesbank did not respond to political pressure and its policies were in line with the wishes of the banking sector.

Using the extended version of Havrilesky's approach (1993) by Maier (2002), Gersl (2006) tried to measure and explain the political pressure on the Czech National Bank (CNB). He concluded that the CNB faced considerable political pressure toward 
a monetary easing in the period 1997-2005, comparable with the pressure on the Federal Reserve and slightly higher than the pressure on the Deutsche Bundesbank. However, the CNB did not succumb to such pressure. Therefore, political pressure did not have any systematic impact on the direction of monetary policy. Hence the legal independence of the CNB was proved to be factual as well.

\subsection{Previous Studies of the Actual Independence of CBs Based on the Fiscal Dominance Hypothesis}

This approach gives more attention to CBs in developing countries, relying on the fiscal dominance hypothesis. In developing countries the fiscal situation will constrain, if not dictate, the CB's activities and therefore determine the extent of the CB's independence. To assess how independent a CB is, Fry (1998) used a simple measure based on an action that all CBs can take: reaction to increased credit demands by the government. Using the change in domestic credit as a proxy for monetary policy, he constructed a monetary policy reaction function. His hypothesis states that the extent of neutralization depends on both the size of the government deficit and the methods by which it is financed. Since governments can finance their deficit in four ways (borrowing at zero cost from the CB, borrowing from domestic commercial banks at below-market interest rates, borrowing abroad in foreign currency, and borrowing at market interest rates from the voluntary domestic private sector), the $\mathrm{CB}$ will be less independent if the government deficit is higher and the government uses the first two methods to finance its deficit.

Fry measured the degree of $\mathrm{CB}$ independence by the value of the neutralization coefficient, that is, the reaction of the $\mathrm{CB}$ to the government's demand for more credit to finance the budget deficit. Since domestic credit plus net foreign assets constitute the assets backing the monetary stock, an increase in net foreign assets must be offset by a decrease in domestic credit to prevent any change in the money stock or to make the $\mathrm{CB}$ able to fulfill its money supply target. To examine whether CBs in developing countries are independent, Fry estimated the neutralization coefficient for a variety of developing countries. His result was that a larger deficit and greater government reliance on the domestic banking system are associated with less neutralization, and consequently less CBI.

As determined in open-economy macroeconomics, a CB-engineered increase in the real interest rate makes domestic government debt more attractive and leads to a real appreciation. However, if the increase in the real interest rate also increases the probability of default on the debt, the effect may be instead to make domestic government debt less attractive, and leads to a real depreciation. That outcome is more likely the higher the initial level of debt, the higher the proportion of foreign-currency-denominated debt, and the higher the price of risk. In such case, fiscal policy, not monetary policy, is the right instrument to decrease inflation. Blanchard (2004) argues that this is the situation found in the Brazilian economy in 2002 and 2003.

\section{Assessment of Previous Studies}

The general conclusion found in the literature pertaining to the empirical studies of legal CBI can be summarized as follows (Ferreira de Mendonca, 2005, and Arnone et al., 2006): (i) among industrial economies there is a strong negative correlation between $d e$ 
jure CBI and inflation; (ii) in developing countries there is no evident relationship between legal CBI and inflation; (iii) there is a positive correlation between the political vulnerability of the $\mathrm{CB}$ and the variation of inflation; (iv) countries in which the monetary authorities announced their goals for inflation presented lower rates of inflation; (v) legal CBI is not correlated with the average real growth rate; (vi) CBs with a higher degree of independence do not finance deficits.

One of the main defects of the legal indices for CBI is that the concept of independence differs across such indices, even though they deal with the same thing. In other words, there is no homogeneous concept of CBI across the legal indices. Ferreira de Mendonca (2005) examines this point using a correlation analysis for the three indices frequently used in empirical studies of CBI (Alesina and Summers, Cukierman, and GMT). Focusing on 15 industrialized countries and performing the analysis for independence indices and independence rankings, the finding was that there is no relationship between these measures of independence after the most independent countries (Germany, Switzerland, and the United States) are omitted from the analysis.

Another defect of the legal indices is that they may not reflect the relationship between the government and the CB that exists in practice. In countries with a lower degree of democracy and where the rule of law is less strongly embedded in the political culture (as in most developing countries), there can be a wide gap between the formal legal institutional arrangements and the actual practice. Thus, for developing countries these CBI indices may not be accurate.

Economists have pointed out other defects in the empirical studies based on the legal indices of CBI (Walsh, 1998, pp. 379-381, and Arnone et al., 2006). (i) Average inflation and the degree of CBI might be jointly determined by the strength of the political constituencies opposed to inflation. In the absence of these constituencies, increasing CBI will not affect inflation. This means that even if the $\mathrm{CB}$ is independent, higher political pressure with no equivalent opposite directions may result in inflation. (ii) Another problem with the estimations of the equation given above is that it fails to correct for country-specific factors that may affect inflation and may also be correlated with the indices of CBI. Correcting for potential bias requires the inclusion of other determinants of inflation in the above equation. (iii) Most economists cast doubt on the relationship between $\mathrm{CBI}$ and average inflation. A complete understanding of this relationship requires a better understanding of the factors that have led to the variations in CBI across countries. The best way to understand such differences is to estimate the above equation directly for one-country rather than cross-section comparisons. However, this task is not easy. (iv) While CBI raises the issue of subjecting the CB to democratic control, the linkage between $\mathrm{CBI}$ and $\mathrm{CB}$ accountability is not clear in most of these studies.

Moreover, the political pressure approach is also criticized. Besides the other flaws of Havrilesky's approach (see Gersl, 2006, p. 4) the major defects are as follows. (i) The channels through which political pressure might work are not clear. (ii) The reaction of the $\mathrm{CB}$ to fiscal policy is ambiguous. (iii) Without complete coordination between fiscal policy and monetary policy, the CB may be coerced to conduct monetary policy in favour of politicians' interests. Such coordination between monetary and fiscal policy reflects the government's desire, side by side with the $\mathrm{CB}$, to curb inflation. This point is also not clear in this literature. 
Some important lessons from the previous studies are as follows. (i) Political pressure on CBs may occur with any degree of CBI. (ii) The degree of inflation resulting from political pressure on CBs depends on whether CBI is factual or only formal. (iii) Since the degree of resulting inflation is the product of the interaction between the political pressure on the $\mathrm{CB}$ for a monetary easing and a higher or lower degree of responsiveness of the $\mathrm{CB}$, then we can assess the degree of $\mathrm{CBI}$ by the ability of the $\mathrm{CB}$ to fulfill its money supply target in the face of political pressure. (iv) One of the crossing points between fiscal policy and monetary policy, and consequently between the government and the CB, is "domestic credit to the government". On the one hand, this is one of the sources of political pressure on the CB. On the other hand, it constitutes an essential part of the assets backing the money supply, and so it is important for monetary policy to keep it under control.

The fiscal dominance hypothesis, discussed by Fry, represents a step in that direction. The reaction of the $\mathrm{CB}$ to the government's demands to increase credit represents a linkage between political pressure on the $\mathrm{CB}$ and CBI. Such a reaction measures to what extent the $\mathrm{CB}$ is actually independent, especially in developing countries. Since CBs in the developed countries may or may not be asked to provide credit to central government, this measure (the reaction of the $\mathrm{CB}$ to the government's demand for higher credit) can be developed into a comprehensive indicator of the actual independence of CBs. In the following two sections I will present Fry's methodology in more detail and then develop it to serve my purposes.

\section{Fry's Methodology}

Fry began with this equation:

$$
D D C Y=f\left(D N F A Y, X_{i}\right)
$$

Where DDCY represents the change in domestic credit scaled by GDP, DNFAY represents the change in net foreign assets scaled by GDP, and $X_{i}$ represents the other explanatory variables other than DNFAY (the gap between domestic inflation and inflation in the industrialized economies, the gap between actual and potential output, economic growth...). Complete sterilization of net foreign assets on the supply of money implies a coefficient of DNFAY equal to -1 . Since domestic credit equals domestic credit to the government (DCG) plus domestic credit to the private sector (DCP), the above equation might be written as follows:

$$
D D C P Y=f\left(D N F A Y, X_{i}\right)-D D C G Y
$$

Where DDCPY is the change in domestic credit to the private sector scaled by GDP, and DDCGY is the change in domestic credit to the government scaled by GDP. The last equation represents the monetary policy reaction function that Fry used to estimate the neutralization coefficient. Complete neutralization of the government's extra borrowing requirements implies a coefficient of -1 for DDCGY. Partial neutralization will produce a coefficient less than zero and higher than -1 , and no neutralization entails a coefficient of zero. Complete neutralization represents the highest level of CBI, while 
zero neutralization represents, in fact, complete subordination of the $\mathrm{CB}$ to the government. Fry argues that, 'a central bank that says to the government "we cannot resist your financing demands, but we shall neutralize them by squeezing the private sector and we shall tell the private sector exactly why we have to squeeze credit" is surely acting more independently than one that simply lets domestic credit rise by the full extent of any extra government borrowing from the banking system.'

Fry used a system of simultaneous equations. He treated the variable (DDCGY) as exogenous, and the variables the inflation gap (INFGAP) and the (DNFAY) as endogenous. He used 3SLS. The instruments are: lagged DNFAY, lagged INFGAP, and lagged money and growth rates, the rate of change in oil prices, the OECD growth rate, and the world interest rate. The estimated monetary policy reaction function was as follows:

$$
\begin{aligned}
& D D C P Y=b_{1} D N F A Y+b_{2} D N F A Y_{t-1}+b_{3} D D C G Y+b_{4} D D C G Y_{t-1}+b_{5} I N F G A P+ \\
& b_{6} L . D N F A Y+b_{7} L . D N F A Y_{t-1}+b_{8} L . D D C G Y+b_{9} L . D D C G Y_{t-1}+b_{10} L . I N F G A P
\end{aligned}
$$

Where, L is a dummy variable taking a value of zero for countries in the high group and one for countries in the low group.

Fry's method does have some defects. (i) Although the variable DDCGY is treated as exogenous the instruments used for the endogenous variables may affect it. For example, an increase in the inflation rate may increase DDCG. But Fry argues that the effect of the inflation rate on DDCG may be offset by an opposite effect on the economic growth rate, as economic growth tends to reduce the government's borrowing requirements. (ii) Even if we assumed that the opposite effects of these two variables are equal, the increase in the budget deficit may shift the whole equation if the CB sought to finance it by issuing new money. If this happened (as is the case in the majority of developing countries) overall domestic credit would increase. In such case we may find a positive relationship between DDCPY and DDCGY. Fry's equation does not consider the case that the coefficient of DDCPY/DDCGY might be positive.

\section{Developing Fry's Methodology}

In spite of these limitations in Fry's methodology, the idea is valuable. We may develop it to derive a comprehensive indicator of factual CBI. The main defect of Fry's methodology is conceptual. If the CB cannot say "no" to the government's demands for higher credit especially when such demands will negatively impact on the target which the CB is willing to meet then the $\mathrm{CB}$ is not factually independent. But the $\mathrm{CB}$ will be efficient if it can fulfill its target, despite the disability to resist the government's demands for higher credit.

The government's credit requirement is a channel for political pressure on the CB. An increasing public debt and budget deficit lead to increasing government demand for credit. Consequently, the political pressure on the $\mathrm{CB}$ will also increase. Without a budget deficit, the government's credit requirements would vanish and the political pressure on the $\mathrm{CB}$ might vanish too. Where the public debt and budget deficit exist with a higher ratio (as in most developing countries) the $\mathrm{CB}$ is not factually independent but the $\mathrm{CB}$ will be efficient if it can neutralize them. "Neutralizing" means that the CB will 
not miss its target. If the $\mathrm{CB}$ have money supply target then to fulfill its target, the $\mathrm{CB}$ has to sterilize changes in NFA. Since the CB cannot affect DCG, the CB will change DCP to offset changes in NFA and fulfill its money supply target.

The criterion for both an efficient and factually independent $C B$ is the ability of the $\mathrm{CB}$ to fulfill its money supply target without squeezing the private sector. Given this money supply target:

$$
\mathrm{M}^{*} \equiv N F A+D C P+D C G
$$

the $\mathrm{CB}$ can fulfill its target (M) ${ }^{*}$ if it can satisfy the right-hand side of (4). To satisfy it, the CB should offset any change in NFA by changing both DCP and DCG. But if the CB cannot resist the government's credit requirements then it must offset the change in the NFA by changing only the DCP. Of course, the CB in such a case is behaving efficiently, but it is not factually independent. Consequently, the coefficient sign of the estimation DCP/NFA, DCG may serve as indicator for both efficient and factually independent CBs. In other words, we can assess both efficiency and independence of CBs simply by estimating (5):

$$
\mathrm{DCPY}=\mathrm{a}_{1}+a_{2} N F A Y+a_{3} D C G Y
$$

Thus, we have these possibilities: (i) if coefficients $a_{2}$ and $a_{3}$ are negative, then the CB behaves in such a way that it fulfills its target, and so the $\mathrm{CB}$ is efficient. But the negative sign of the coefficient $a_{3}$ indicates that the legal (formal) independence granted to the $\mathrm{CB}$ is not factual; (ii) if coefficients $a_{2}$ and $a_{3}$ are positive, then the CB does not behave in such a way that it fulfills its target, and so the $\mathrm{CB}$ is not efficient although the CB is factually independent according to the positive sign of the coefficient $a_{3}$; (iii) if the sign of the coefficient $a_{2}$ is negative and the sign of the coefficient $a_{3}$ is positive then the CB is efficient and factually independent; (iv) conversely, if the sign of the coefficient $a_{2}$ is positive and the sign of the coefficient $a_{3}$ is negative then the CB is not efficient and not factually independent. In all of these cases the negative sign of the coefficient $a_{2}$ indicates that the $\mathrm{CB}$ behaves efficiently whereas the negative sign of the coefficient $\mathrm{a}_{3}$ indicates that the formal independence granted to the $\mathrm{CB}$ is not factual. The main assumption here is that the $\mathrm{CB}$ does not follow the cheep money policy.

In fact, the above possibilities of the equation 5 are confined with the target which the CBs are willing to meet. Such a target is derived from the applied monetary policy regime. Therefore, the above possibilities of the equation 5 may apply directly on the case in which the applied monetary policy regime is "the monetary targeting regime". But if, for instance, the applied monetary policy regime is "the exchange rate targeting regime" or "the inflation targeting regime" then the above possibilities of the equation 5 will differ.

If the applied monetary policy regime is the exchange rate targeting rather than the monetary targeting the equation 5 is valid to detect both efficiency and independence of the $\mathrm{CB}$. The only change in the equation 5 in such a case will be in the sign of the coefficient $a_{2}$. Since the CB is now targeting the exchange rate then it must also react for any change in the NFA. To neutralize the effect of the change in the NFA on the targeted level (range) of the exchange rate the domestic credit has to move parallel with the NFA. 
Consequently, the positive sign of the coefficient $a_{2}$ in the equation 5 will serve as indicator that the $\mathrm{CB}$ behaves efficiently. Whereas, the negative sign of the coefficient $a_{3}$ will stay indicating that the formal independence granted the CB is not factual.

The limit to the equation 5 is the case in which the applied monetary policy regime is the inflation targeting regime. On the one hand, the negative sign of the coefficient $a_{3}$ may indicate that the formal independence granted to the $\mathrm{CB}$ is not factual. The negative sign of the coefficient $a_{3}$ will exist if the CB is coerced to finance the government when the actual rate of inflation is equal to, or higher than, the target level. On the other hand, the positive sign of the coefficient $a_{3}$ does not necessarily mean that the formal independence of the $\mathrm{CB}$ is factual. Simply, because the CB under the inflation targeting regime will let domestic credit to increase if the actual rate of inflation is lower than the target level. In such a case the sign of the coefficient $a_{3}$ will be positive without any indication for factual independence.

In the following section I will use this simple indicator to assess the legal independence granted to the Central Bank of Egypt (CBE).

\section{Assessing the Legal Independence of the Central Bank of Egypt (CBE)}

\subsection{The Legal Relationship between the Government and the CBE}

At the beginning of the 1990s, Egypt - acting in agreement with the IMF and WB - implemented an "Economic Reform and Structural Adjustment Program" (ERSAP). The purpose was to reform the country's macroeconomic policies and increase the role of the private sector in the economy. Under the ERSAP, Egypt liberalized its interest rate in 1991 and applied an active privatization program starting from this date. During this period the CBE was targeting the exchange rate. In January 2003, Egypt floated its exchange rate. The CBE changed its policy from exchange rate targeting to monetary growth targeting as an intermediate objective for monetary policy. New legislation was promulgated. Law No. 88 of 2003, as amended by Law No. 162 of 2004 and Law No. 93 of 2005 , is a comprehensive law governing the CB, the banking sector, and money ${ }^{3}$.

Under the current new legislation, the final objective of monetary policy is to achieve price stability. The CBE acts as a financial advisor and agent for the government. Consequently, the $\mathrm{CBE}$ executes banking transactions pertaining to the government and public legal persons, as well as internal and external finance, with banks according to the conditions set by the BoD. The CBE, acting as the bank of the government, charges fees on the services it renders to the government and public legal persons according to its own list of fees on banking services, and the government may designate the CBE to act on its behalf in issuing government bonds and bills of all types of maturities. The CBE extends financing to the government, upon its request, to cover the seasonal deficit on the general budget, provided that the amount of such finance does

3 Article 1 of this Law repeals the following former laws: (i) the banks and credit law promulgated by Law No. 163 of 1957, (ii) Law No. 120 of 1975 concerning the central bank of Egypt and the banking sector, (iii) Law No. 205 of 1990 concerning the secrecy of bank accounts, (iv) Law No. 38 of 1994 regulating dealing in foreign exchange, and (v) Law No. 155 of 1998 regulating the private sector's contribution to the capital of public sector banks. See: www.cbe.org.eg. 
not exceed $10 \%$ of the average revenues of the general budget in the three previous years. The term of such finance is three months renewable for other similar periods, with a maximum of twelve months. The conditions concerning this finance are determined upon agreement between the ministry of finance and the $\mathrm{ECB}^{4}$.

\subsection{The Methodology and the Data}

The main objective is to assess whether the legal independence granted to the CBE under the latest legislation promulgated in 2005 is factual. As I mentioned, the CBE applied two different monetary policy regimes during the period 1991-2007. Before 2003 the applied monetary policy regime was "the exchange rate targeting regime". In the beginning of 2003 the CBE liberalized the exchange rate and switched to the monetary targeting regime. To achieve our purpose I will estimate the equation 5 for the period 1991-2007 and test whether the latest legislation involved significant change on the CBE independence.

As the period of the study is relatively short, I will use quarterly data (IFS-CD, 2008) to estimate the equation 5. Because the quarterly data of GDP are not available for Egypt in the source of data, I will use the variables in the equation 5 in the level-form.

\subsection{Estimation Results ${ }^{5}$}

The unit root test revealed that the variables in the equation 5 are not stationary during the period 1991Q1-2007Q1. According to AIC (20 lags) the first difference of the logarithmic value of the variables DCP and NFA are stationary. Whereas the first difference of the DCG is stationary at level $5 \%$, but according to SIC (20 lags) it is stationary at level $1 \%$. In the light of these results, the equation 5 takes the following form;

$$
\triangle L n D C P=a_{1}+a_{2} \Delta L n N F A+a_{3} \Delta D C G
$$

Table 1 shows the estimation results of the equation 6 . As these results suggest, the statistical value of Durbin-Watson is undetermined. The LM test revealed that the regression in the Table 1 includes positive serial autocorrelation. Using the value $[1-(\mathrm{D}-\mathrm{W}) / 2=0.19]$ as approximation for the autocorrelation coefficient, I transformed the equation 6 to the following form;

$$
\triangle L n D C P W=\beta_{1}+\beta_{2} \triangle L n N F A W+\beta_{3} \triangle D C G W
$$

Where, $\Delta$ Ln DCPW $=\Delta$ Ln DCP $-0.19(\operatorname{lag} \Delta$ Ln DCP $), \Delta$ Ln NFAW $=\Delta$ LnNFA -0.19 (lag $\Delta$ Ln NFA), and $\Delta$ DCGW $=\Delta \mathrm{DCG}-0.19$ (lag $\Delta$ DCG).

Table 2 shows the estimation results of the equation 7. According to the statistical value of Durbin-Watson there is no serial autocorrelation. According to the unite root test and the ACF the residuals from the equation 7 were stationary. The Johansen cointegration test

4 Articles 26-27.

5 The steps of the estimation process are available upon request. 
indicated a cointegrating relationship between the variables in the equation 7 . The Granger causality test indicated a bilateral causality between the DCP and the DCG.

The results of the above analysis indicate that a significant and negative relationship exists between the change of the DCP and the change of the DCG. As the Egyptian government claims that the latest legislation gives the CBE higher level of independence, I used the Chow test to explore whether there is significant change. The Chow test did not detect any significant change of the $\mathrm{CBE}$ independence after the new legislation.

Table 1

Estimation Results of the Equation 6

Dependent Variable: DIF_LN_DCP

Sample (adjusted): 1991Q2 2007Q1

Included observations: 64 after adjustment

\begin{tabular}{|l|c|l|c|c|}
\hline \multicolumn{1}{|c|}{ Variable } & Coefficient & \multicolumn{1}{c|}{ Std. Error } & t-Statistic & Prob. \\
\hline C & 0.047747 & 0.004046 & 11.80229 & 0.0000 \\
\hline DIF_LN_NFA & -0.055529 & 0.014781 & -3.756837 & 0.0004 \\
\hline DIF_DCG & $-1.75 E-06$ & $6.39 E-07$ & -2.743002 & 0.0080 \\
\hline Adjusted R-squared & 0.212529 & Akaike info criterion & -4.363801 \\
\hline Schwarz criterion & -4.262603 & F-statistic & 9.501464 \\
\hline Durbin-Watson stat. & 1.624221 & Prob. (F-statistic) & 0.000256 \\
\hline
\end{tabular}

Table 2

Estimation Results of the Equation 7

Dependent Variable: DIF_LN_DCPW

Sample (adjusted): 1991Q3 2007Q1

Included observations: 63 after adjustments

\begin{tabular}{|l|c|c|c|c|}
\hline \multicolumn{1}{|c|}{ Variable } & Coefficient & \multicolumn{1}{c|}{ Std. Error } & t-Statistic & Prob. \\
\hline C & 0.038430 & 0.003886 & 9.888195 & 0.0000 \\
\hline DIF_LN_NFAW & -0.073245 & 0.031604 & -2.317572 & 0.0240 \\
\hline DIF_DCGW & $-1.39 E-06$ & $6.57 E-07$ & -2.121778 & 0.0381 \\
\hline Adjusted R-squared & 0.114092 & F-statistic & 4.927960 \\
\hline Schwarz criterion & -4.305573 & Prob. (F-statistic) & 0.010492 \\
\hline Durbin-Watson stat. & 1.872994 & Akaike info criterion & -4.408499 \\
\hline
\end{tabular}

\section{Conclusion}

To assess whether the legal independence granted to the Central Bank of Egypt (CBE) under the latest legislation is factual, I followed Fry's methodology, which assumes that the level of independence of the central bank is determined by fiscal attributes. In an attempt to develop Fry's method, I used a simple criterion to assess the central bank's independence, namely, that the central bank is actually independent if it can fulfill its money supply target without squeezing private sector. Applying this criterion to the $\mathrm{CBE}$, we find that the legal independence granted to the $\mathrm{CBE}$ under the latest legislation is not factual. 


\section{References}

Alesina, A. (1988), "Macroeconomics and Politics", in NBER Macroeconomics Annual 1988. Cambridge, MA : MIT Press, pp. 17-52.

Alesina, A. (1989), "Politics and Business Cycles in Industrial Democracies". Economic Policy, 8, pp. 55-98.

Alesina, A., Summers, L. H. (1993), "Central Bank Independence and Macroeconomic Performance: Some Comparative Evidence”. Journal of Money, Credit and Banking, 25 (2), pp. 151-162.

Arnone, M., Laurens, B. J., Segalotto, J. F. (2006a), "The Measurement of Central Bank Autonomy: Survey of Models, Indicators, and Empirical Evidence". IMF Working Paper.

Arnone, M., Laurens, B. J., Segalotto, J. F. (2006b), "Measures of Central Bank Autonomy: Empirical Evidence for OECD, Developing, and Emerging Market Economies". IMF Working Paper.

Bade, R., Parkin, M. (1977), Central Bank Laws and Monetary Policies: A Preliminary Investigation. London, Ontario, Canada : University of Western Ontario.

Blanchard, O. (2004), "Fiscal Dominance and Inflation Targeting: Lessons from Brazil". MIT Working Paper.

Blanchard, O., Fisher, S. (1993), Lectures on Macroeconomics. Cambridge, MA : MIT Press.

Chotareas, G. E., Miller, S. M. (2002), "Optimal Central Bank Contracts and Common Agency". Working Paper.

Cukierman, A. (1992). Central Bank Strategy, Credibility and Independence. Cambridge, MA : MIT Press.

Debelle, G., Fisher, S. (1994), "How Independent Should a Central Bank Be?”. Federal Reserve Bank of Boston.

Drazen, A. (2002), "Laying Low During Elections: Political Pressure and Monetary Policy Accommodation". Tel Aviv University, University of Maryland, CEPR, and NBER.

Eijffinger, S., Keulen, M. (1995), "Central Bank Independence in Another Eleven Countries". BNL Quarterly Review, 192.

Eijffinger, S., Schaling, E. (1993). "Central Bank Independence in Twelve Industrial Countries". BNL Quarterly Review, 184, pp. 64-68.

Ferreira de Mendonca, H. (2005). "Central Bank Independence and its Relationship to Inflation". CEPAL Review, 81.

Fry, M. J. (1998), "Assessing Central Bank Independence in Developing Countries: Do Actions Speak Louder than Words?" Oxford Economic Papers, 50, pp. 512-529.

GersI, A. (2006), "Political Pressure on Central Banks: The Case of the Czech National Bank". IES Working Paper.

Grilli, V., Masciandaro, D., Tabellini, G. (GMT) (1991), "Political and Monetary Institutions and Public Financial Policies in the Industrial Countries". Economic Policy, 13, pp. 341-392.

Havrilesky, T. (1993), The Pressures on American Monetary Policy. Boston : Kluwer Academic Publisher.

Mahadeva, L., Sterne, G. (2000), Monetary Policy Frameworks in a Global Context. London and New York : Routledge, Bank of England.

Maier, P., Sturm, J. E., de Haan, J. (2002), "Political Pressure on the Bundesbank: An Empirical Investigation Using the Havrilesky Approach". Journal of Macroeconomics, 24, pp. 103-123.

Meyer, L. H. (2000), "The Politics of Monetary Policy: Balancing Independence and Accountability". BIS Review, 49.

Walsh, C. E. (1998), Monetary Theory and Policy. Cambridge, MA : MIT Press 


\section{Appendix}

\section{THE ESTIMATION PROCESS OF THE EQUATION 5}

Our objective is to estimate the following equation;

$$
D C P=a_{1}+a_{2} N F A+a_{3} D C G
$$

The next sections include our steps for the estimation process.

\section{The Stationarity of the Time Series DCP, NFA, and DCG}

The stochastic process is said to be stationary (weakly stationarity) if its mean and variance are constant over time, and the value of the covariance between the two random variables of the process depends only on the distance or the lag between the two time periods and not on the time. Conversely, a non-stationary process will have a time-varying mean or a time-varying variance or both. Also, regressing two or more non-stationary time series may deliver misleading results, i.e. spurious regression.

Plotting the time series DCP, NFA, and DCG with the time gives intuition that they are non-stationary, as shown in the Figure 1.

Figure 1

The Behavior of the Variables DCP, NFA, and DCG

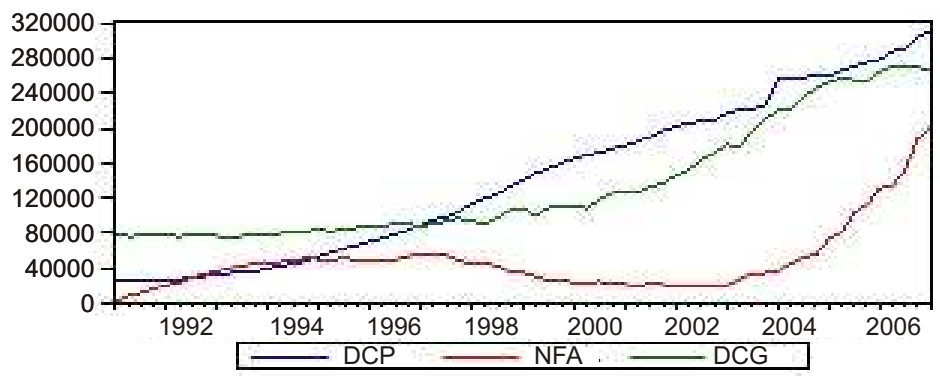

One of the most popular tests of stationarity in the past several years is the unite root test. I used the Augmented Dickey-Fuller (ADF) unit root test to determine the stationarity time series of the variables DCP, NFA, and $\mathrm{DCG}^{6}$. The ADF equation for a given time series $\left(\mathrm{Y}_{\mathrm{t}}\right)$ takes this form:

$$
\Delta \mathrm{Yt}=\underset{\mathrm{i}=1}{\beta_{0}}+\beta_{1} t+\lambda \mathrm{Y}_{\mathrm{t}-1}+\sum \alpha_{1} \Delta \mathrm{Y}_{\mathrm{t}-\mathrm{i}}+\varepsilon_{\mathrm{t}},
$$

where $\varepsilon_{\mathrm{t} \sim \operatorname{iid}\left(o, \sigma^{2}\right)}$, and $\lambda=(\rho-1)$

6 The ADF test takes care of the serial correlation by adding the lagged difference terms of the dependent variable whilst, the PP test uses nonparametric statistical methods to take care of the serial correlation. 
The ADF test is regularly performed under three assumptions regarding the parameters of the equation 1 . In each case the null hypothesis is that the value of the parameter $\lambda$ is zero, i.e. $\rho$ equals one, or the process under consideration involved unite root and consequently it is not stationary.

I performed the unit root test on the time series of the variables DCP, NFA, and DCG under the three assumptions regarding the parameters of equation 1 . The three time series of the variables DCP, NFA, and DCG are found including unit root as shown in the Tables $1-3$.

Table 1

Testing the Stationarity of (DCP)

\begin{tabular}{|c|c|c|c|c|c|}
\hline \multirow{2}{*}{ Case } & \multicolumn{3}{|c|}{ ADF Equation } & \multicolumn{2}{|c|}{ ADF Test } \\
\hline & $\beta_{0}$ & $\beta_{1}$ & $\lambda$ & ADF Statistic (t) & ADF Critical Values \\
\hline 1 & $\mathbf{0}$ & $\mathbf{0}$ & 0.026 & 7.959 & $\begin{array}{r}1 \% \text { level }-2.601596 \\
5 \% \text { level }-1.945987 \\
10 \% \text { level }-1.613496 \\
\end{array}$ \\
\hline 2 & 2523.46 & $\mathbf{0}$ & 0.0137 & 2.294 & $\begin{array}{rr}1 \% \text { level } & -3.536587 \\
5 \% \text { level } & -2.907660 \\
10 \% \text { level } & -2.591396 \\
\end{array}$ \\
\hline 3 & 12.572 & 705.12 & -0.131 & -3.118 & 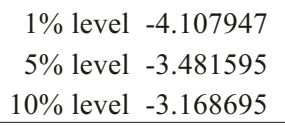 \\
\hline
\end{tabular}

Table 2

Testing the Stationarity of NFA

\begin{tabular}{|c|c|c|c|c|c|c|}
\hline \multirow{2}{*}{ Case } & \multicolumn{3}{|c|}{ ADF Equation } & \multicolumn{3}{|c|}{ ADF Test } \\
\hline & $\beta_{0}$ & $\beta_{1}$ & $\lambda$ & ADF Statistic (t) & ADF C & al Values \\
\hline 1 & 0 & $\mathbf{0}$ & 0.011 & 0.614 & $\begin{array}{r}1 \% \text { level } \\
5 \% \text { level } \\
10 \% \text { level }\end{array}$ & $\begin{array}{r}-2.606911 \\
-1.946764 \\
-1.613062 \\
\end{array}$ \\
\hline 2 & 3251.877 & $\mathbf{0}$ & -0.061 & -0.769 & $\begin{array}{r}1 \% \text { level } \\
5 \% \text { level } \\
10 \% \text { level }\end{array}$ & $\begin{array}{r}-3.571310 \\
-2.922449 \\
-2.599224 \\
\end{array}$ \\
\hline 3 & -21280.67 & 690.66 & -0.103 & -1.166 & $\begin{array}{r}1 \% \text { level } \\
5 \% \text { level } \\
10 \% \text { level }\end{array}$ & $\begin{array}{r}-4.170583 \\
-3.510740 \\
-3.185512\end{array}$ \\
\hline
\end{tabular}


Table 3

Testing the Stationarity of DCG

\begin{tabular}{|c|c|c|c|c|c|c|}
\hline \multirow{2}{*}{ Case } & \multicolumn{3}{|c|}{ ADF Equation } & \multicolumn{3}{|c|}{ ADF Test } \\
\hline & $\beta_{0}$ & $\beta_{1}$ & $\lambda$ & ADF Statistic (t) & ADF $\mathrm{Cr}$ & al Values \\
\hline 1 & $\mathbf{0}$ & $\mathbf{0}$ & 0.019 & 1.29 & $\begin{array}{r}1 \% \text { level } \\
5 \% \text { level } \\
10 \% \text { level }\end{array}$ & $\begin{array}{l}-2.614029 \\
-1.947816 \\
-1.612492\end{array}$ \\
\hline 2 & -13961.42 & $\mathbf{0}$ & 0.2 & 1.7 & $\begin{array}{r}1 \% \text { level } \\
5 \% \text { level } \\
10 \% \text { level }\end{array}$ & $\begin{array}{l}-3.571310 \\
-2.922449 \\
-2.599224\end{array}$ \\
\hline 3 & 2843.85 & 193.59 & -0.071 & -2.916 & $\begin{array}{r}1 \% \text { level } \\
5 \% \text { level } \\
10 \% \text { level }\end{array}$ & $\begin{array}{l}-4.124265 \\
-3.489228 \\
-3.173114\end{array}$ \\
\hline
\end{tabular}

According to AIC (for 20 lags) the first difference of the logarithmic value of the variables DCP and NFA are stationary as shown in Tables 4-5. The difference of the DCG is stationary at level $5 \%$ as shown in Table 6, but according to SIC it was stationary at level 1\%. Figure 2 shows the stationary behaviour of the three variables.

Table 4

Testing the Stationarity of $\Delta$ (Ln-DCP)

\begin{tabular}{|c|c|c|c|c|c|c|}
\hline \multirow{2}{*}{ Case } & \multicolumn{3}{|c|}{ ADF Equation } & \multicolumn{3}{|c|}{ ADF Test } \\
\hline & $\beta_{0}$ & $\beta_{1}$ & $\lambda$ & ADF Statistic (t) & ADF Cri & cal Values \\
\hline 1 & $\mathbf{0}$ & $\mathbf{0}$ & -0.057 & -0.785 & $\begin{array}{r}1 \% \text { level } \\
5 \% \text { level } \\
10 \% \text { level }\end{array}$ & $\begin{array}{r}-2.604073 \\
-1.946348 \\
-1.613293 \\
\end{array}$ \\
\hline 2 & 0.015 & $\mathbf{0}$ & -0.36 & -2.35 & $\begin{array}{r}1 \% \text { level } \\
5 \% \text { level } \\
10 \% \text { level }\end{array}$ & $\begin{array}{r}-3.544063 \\
-2.910860 \\
-2.593090 \\
\end{array}$ \\
\hline 3 & 0.039 & -0.0004 & -0.64 & -5.6 & $\begin{array}{r}1 \% \text { level } \\
5 \% \text { level } \\
10 \% \text { level }\end{array}$ & $\begin{array}{r}-4.110440 \\
-3.482763 \\
-3.169372 \\
\end{array}$ \\
\hline
\end{tabular}

Table 5

Testing the Stationarity of $\Delta$ (Ln-NFA)

\begin{tabular}{|c|c|c|c|c|c|c|}
\hline \multirow{2}{*}{ Case } & \multicolumn{3}{|c|}{ ADF Equation } & \multicolumn{3}{|c|}{ ADF Test } \\
\hline & $\beta_{0}$ & $\beta_{1}$ & $\lambda$ & ADF Statistic (t) & $\mathrm{ADF} \mathrm{Cr}_{\mathbf{r}}$ & al Values \\
\hline 1 & $\mathbf{0}$ & $\mathbf{0}$ & -0.32 & -2.656 & $\begin{array}{r}1 \% \text { level } \\
5 \% \text { level } \\
10 \% \text { level }\end{array}$ & $\begin{array}{r}-2.604073 \\
-1.946348 \\
-1.613293\end{array}$ \\
\hline 2 & 0.009 & $\mathbf{0}$ & -0.355 & -2.7 & $\begin{array}{r}1 \% \text { level } \\
5 \% \text { level } \\
10 \% \text { level }\end{array}$ & $\begin{array}{r}-3.544063 \\
-2.910860 \\
-2.593090 \\
\end{array}$ \\
\hline 3 & -0.042 & 0.001 & -0.402 & -3.103 & $\begin{array}{r}1 \% \text { level } \\
5 \% \text { level } \\
10 \% \text { level }\end{array}$ & $\begin{array}{r}-4.118444 \\
-3.486509 \\
-3.171541\end{array}$ \\
\hline
\end{tabular}


Table 6

Testing the Stationarity of $\Delta$ (DCG)

\begin{tabular}{|c|c|c|c|c|c|c|}
\hline \multirow{2}{*}{ Case } & \multicolumn{3}{|c|}{ ADF Equation } & \multicolumn{3}{|c|}{ ADF Test } \\
\hline & $\beta_{0}$ & $\beta_{1}$ & $\lambda$ & ADF Statistic (t) & ADF C & Values \\
\hline 1 & $\mathbf{0}$ & $\mathbf{0}$ & -0.171 & -1.283 & $\begin{array}{r}1 \% \text { level } \\
5 \% \text { level } \\
10 \% \text { level }\end{array}$ & $\begin{array}{l}-2.604073 \\
-1.946348 \\
-1.613293\end{array}$ \\
\hline 2 & 1361.3 & $\mathbf{0}$ & -0.373 & -1.016 & $\begin{array}{r}1 \% \text { level } \\
5 \% \text { level } \\
10 \% \text { level }\end{array}$ & $\begin{array}{l}\mathbf{- 3 . 5 7 4 4 4 6} \\
-2.923780 \\
-2.599925\end{array}$ \\
\hline 3 & -8338.45 & 410.4 & -2.91 & -3.67 & $\begin{array}{r}1 \% \text { level } \\
5 \% \text { level } \\
10 \% \text { level } \\
\end{array}$ & $\begin{array}{l}-4.156734 \\
-3.504330 \\
-3.181826 \\
\end{array}$ \\
\hline
\end{tabular}

Figure 2

The Stationary Behaviour of the Variables $\Delta$ LnDCP, $\Delta$ LnNFA, and $\Delta$ DCG

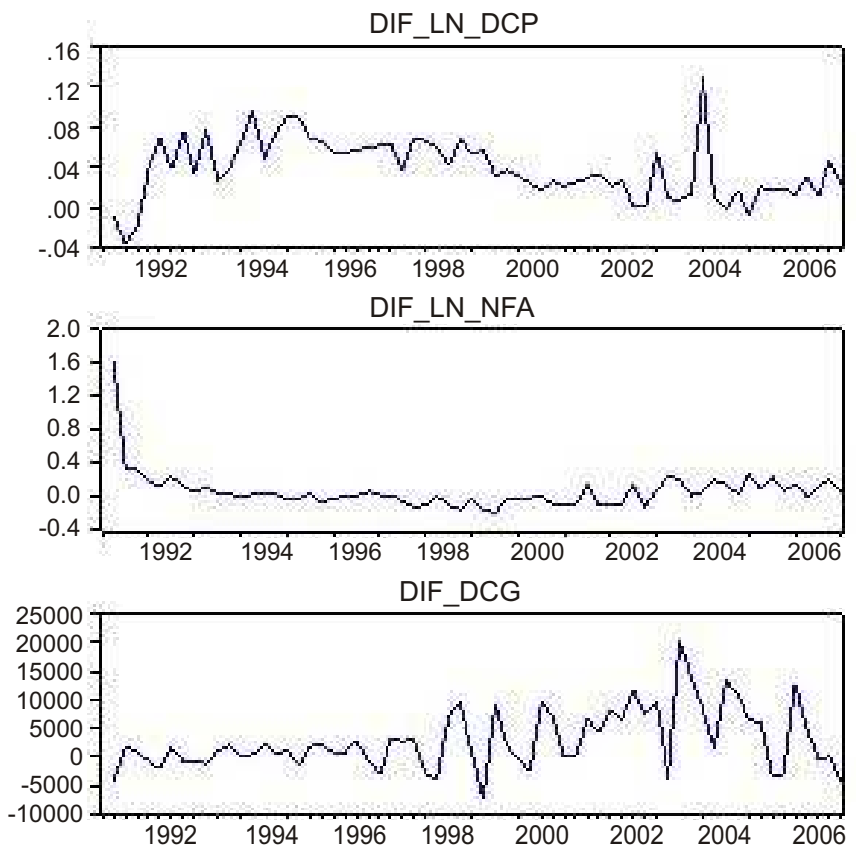

\section{Estimation Results}

In the light of the above results, equation 5 will take the following form;

$$
\triangle L n-D C P=a_{1}+a_{2} \Delta \mathrm{Ln}-N F A+a_{3} \Delta D C G
$$


I estimate the equation 6 for the Egyptian economy during the period 1991-2007. As shown in Table 7, the statistical value of Durbin-Watson is undetermined. But the LM test, as shown in Table 8, indicates to positive serial autocorrelation. Using the value $[1-(\mathrm{D}-\mathrm{W}) / 2=0.19]$ as approximation for the autocorrelation coefficient, I transformed the equation 6 to eliminate the serial autocorrelation. Equation 7 indicates to the transformed form of the equation 6 .

$$
\triangle L n-D C P W=\beta_{1}+\beta_{2} \Delta L n-N F A W+\beta_{2} \Delta D C G W
$$

Where, $\Delta$ Ln-DCPW $=\Delta$ Ln-DCP $-0.19(\operatorname{lag} \Delta$ Ln-DCP $), \Delta$ Ln- NFAW $=\Delta$ Ln- NFA -0.19 (lag $\Delta$ Ln-NFA), and $\Delta$ DCGW $=\Delta$ DCG -0.19 (lag $\Delta$ DCG).

Table 9 shows the estimation results of the equation 7 . According to the statistical value of Durbin-Watson there is no serial autocorrelation. The behaviour of the residuals from the equation 7 is stationary, as shown in Figure 3. Both the unite root test and the ACF show that the residuals from the equation 7 are stationary. The Johansen cointegration test, as shown in Table 10, indicates to a cointegrating relationship between the variables in the equation 7. The Granger causality test, as shown in Table 11, indicates to a bilateral causality between the DCP and the DCG. As the Egyptian government claims that the latest legislation gives the CBE higher level of independent, I used the Chow test to explore whether there is significant change. The Chow test did not detect any significant change of the CBE independence after the new legislation, as shown in Tables 12-13.

Table 7

The Estimation Results of the Equation 6 during the Period 1991-2007

\begin{tabular}{|c|c|c|c|c|}
\hline \multicolumn{5}{|c|}{$\begin{array}{l}\text { Included observations: } 64 \text { after adjustments } \\
\text { Dependent Variable: DIF_LN_DCP } \\
\text { Method: Least Squares } \\
\text { Sample (adjusted): 1991Q2 2007Q1 }\end{array}$} \\
\hline Variable & Coefficient & Std. Error & t-Statistic & Prob. \\
\hline $\mathrm{C}$ & 0.047747 & 0.004046 & 11.80229 & 0.0000 \\
\hline DIF_LN_NFA & -0.055529 & 0.014781 & -3.756837 & 0.0004 \\
\hline DIF_DCG & $-1.75 \mathrm{E}-06$ & $6.39 \mathrm{E}-07$ & -2.743002 & 0.0080 \\
\hline R-squared & 0.237528 & Mean dependent var. & 0.038523 & \\
\hline Adjusted R-squared & 0.212529 & S.D. dependent var. & 0.030069 & \\
\hline S.E. of regression & 0.026684 & Akaike info criterion & -4.363801 & \\
\hline Sum squared resid. & 0.043433 & Schwarz criterion & -4.262603 & \\
\hline Log likelihood & 142.6416 & F-statistic & 9.501464 & \\
\hline Durbin-Watson stat. & 1.624221 & Prob. (F-statistic) & 0.000256 & \\
\hline
\end{tabular}


Table 8

The LM Test for the Regression in Table 7

\begin{tabular}{|c|c|c|c|c|}
\hline \multicolumn{5}{|c|}{ Breusch-Godfrey Serial Correlation LM Test } \\
\hline F-statistic & 3.119698 & Prob. F $(2,59)$ & \multicolumn{2}{|c|}{0.051534} \\
\hline Obs*R-squared & 6.120862 & Prob. Chi-Square(2) & \multicolumn{2}{|c|}{0.046868} \\
\hline \multicolumn{5}{|c|}{ Test Equation: } \\
\hline \multicolumn{5}{|c|}{ Dependent Variable: RESID } \\
\hline \multicolumn{5}{|c|}{ Method: Least Squares } \\
\hline \multicolumn{5}{|c|}{ Sample: 1991Q2 2007Q1 } \\
\hline \multicolumn{5}{|c|}{ Included observations: 64} \\
\hline \multicolumn{5}{|c|}{ Presample missing value lagged residuals set to zero. } \\
\hline Variable & Coefficient & Std. Error & t-Statistic & Prob. \\
\hline $\mathrm{C}$ & -0.001029 & 0.003998 & -0.257382 & 0.7978 \\
\hline DIF_LN_NFA & 0.003161 & 0.014378 & 0.219842 & 0.8268 \\
\hline DIF_DCG & $2.24 \mathrm{E}-07$ & $6.59 \mathrm{E}-07$ & 0.340237 & 0.7349 \\
\hline $\operatorname{RESID}(-1)$ & 0.144013 & 0.135779 & 1.060639 & 0.2932 \\
\hline $\operatorname{RESID}(-2)$ & 0.257194 & 0.127930 & 2.010432 & 0.0490 \\
\hline R-squared & 0.095638 & Mean dependent var. & $1.08 \mathrm{E}-19$ & \\
\hline Adjusted R-squared & 0.034326 & S.D. dependent var. & 0.026257 & \\
\hline S.E. of regression & 0.025802 & Akaike info criterion & -4.401827 & \\
\hline Sum squared resid. & 0.039279 & Schwarz criterion & -4.233164 & \\
\hline Log likelihood & 145.8585 & F-statistic & 1.559849 & \\
\hline Durbin-Watson stat. & 1.990287 & Prob. (F-statistic) & 0.196928 & \\
\hline
\end{tabular}

Table 9

Estimation Results of the Equation 7 for the Period 1991-2007

\begin{tabular}{|c|c|c|c|c|}
\hline \multicolumn{5}{|c|}{$\begin{array}{l}\text { Dependent Variable: DIF_LN_DCPW } \\
\text { Method: Least Squares } \\
\text { Sample (adjusted): 1991Q3 2007Q1 } \\
\text { Included observations: } 63 \text { after adjustments }\end{array}$} \\
\hline Variable & Coefficient & Std. Error & t-Statistic & Prob. \\
\hline $\mathrm{C}$ & 0.038430 & 0.003886 & 9.888195 & 0.0000 \\
\hline DIF_LN_NFAW & -0.073245 & 0.031604 & -2.317572 & 0.0240 \\
\hline DIF_DCGW & $-1.39 \mathrm{E}-06$ & $6.57 \mathrm{E}-07$ & -2.121778 & 0.0381 \\
\hline R-squared & 0.143138 & Mean dependent var. & 0.032204 & \\
\hline Adjusted R-squared & 0.114092 & S.D. dependent var. & 0.027703 & \\
\hline S.E. of regression & 0.026075 & Akaike info criterion & -4.408499 & \\
\hline Sum squared resid. & 0.040115 & Schwarz criterion & -4.305573 & \\
\hline Log likelihood & 139.6635 & F-statistic & 4.927960 & \\
\hline Durbin-Watson stat. & 1.872994 & Prob. (F-statistic) & 0.010492 & \\
\hline
\end{tabular}


Figure 3

The Residuals from the Regression 7

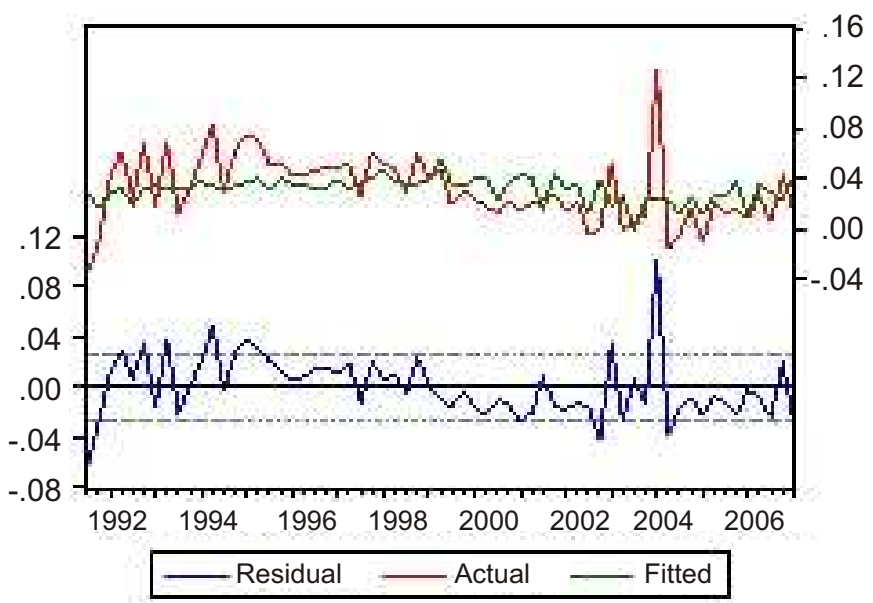

Table 10

Johansen Cointegration Test

\begin{tabular}{|c|c|c|c|c|}
\hline \multicolumn{5}{|c|}{$\begin{array}{l}\text { Sample (adjusted): 1992Q2 2007Q1 } \\
\text { Included observations: } 60 \text { after adjustments } \\
\text { Trend assumption: Linear deterministic trend } \\
\text { Series: DIF_LN_DCPW DIF_LN_NFAW DIF_DCGW } \\
\text { Lags interval (in first differences): } 1 \text { to } 2\end{array}$} \\
\hline \multicolumn{5}{|c|}{ Unrestricted Cointegration Rank Test (Trace) } \\
\hline $\begin{array}{c}\text { Hypothesized } \\
\text { No. of CE(s) }\end{array}$ & Eigenvalue & $\begin{array}{c}\text { Trace } \\
\text { Statistic } \\
\end{array}$ & $\begin{array}{c}0.05 \\
\text { Critical Value } \\
\end{array}$ & Prob.** \\
\hline None * & 0.294515 & 41.19914 & 29.79707 & 0.0016 \\
\hline At most $1 *$ & 0.193892 & 20.26693 & 15.49471 & 0.0088 \\
\hline At most $2 *$ & 0.115068 & 7.334643 & 3.841466 & 0.0068 \\
\hline \multicolumn{5}{|c|}{$\begin{array}{l}\text { Trace test indicates } 3 \text { cointegrating eqn(s) at the } 0.05 \text { level } \\
* \text { denotes rejection of the hypothesis at the } 0.05 \text { level } \\
* * \text { MacKinnon-Haug-Michelis (1999) p-values }\end{array}$} \\
\hline \multicolumn{5}{|c|}{ Unrestricted Cointegration Rank Test (Maximum Eigenvalue) } \\
\hline $\begin{array}{l}\text { Hypothesized } \\
\text { No. of CE(s) }\end{array}$ & Eigenvalue & $\begin{array}{c}\text { Max-Eigen } \\
\text { Statistic }\end{array}$ & $\begin{array}{c}0.05 \\
\text { Critical Value } \\
\end{array}$ & Prob.** \\
\hline None & 0.294515 & 20.93222 & 21.13162 & 0.0533 \\
\hline At most 1 & 0.193892 & 12.93228 & 14.26460 & 0.0803 \\
\hline At most $2^{*}$ & 0.115068 & 7.334643 & 3.841466 & 0.0068 \\
\hline
\end{tabular}


Table 11

Granger Causality Test

Pairwise Granger Causality Tests

Date: 03/18/08 Time: 15:25

Sample: 1991Q1 2007Q1

Lags: 3

\begin{tabular}{|l|c|c|l|}
\hline Null Hypothesis: & Obs. & F-Statistic & Probability \\
\hline DIF_DCGW does not Granger Cause DIF_LN_DCPW & 60 & 3.11085 & 0.03393 \\
\hline DIF_LN_DCPW does not Granger Cause DIF_DCGW & 4.92927 & 0.00430 & \\
\hline
\end{tabular}

Table 12

Chow Breakpoint Test

\begin{tabular}{|l|c|c|c|}
\hline \multicolumn{4}{|c|}{ Chow Breakpoint Test: 2005Q4 } \\
\hline F-statistic & 0.762385 & Prob. F(3,57) & 0.519855 \\
\hline Log likelihood ratio & 2.478513 & Prob. Chi-Square(3) & 0.479187 \\
\hline
\end{tabular}

Table 13

Chow Forecast Test

\begin{tabular}{|c|c|c|c|c|}
\hline \multicolumn{5}{|c|}{ Chow Forecast Test: Forecast from 2005Q4 to 2007Q1 } \\
\hline F-statistic & 0.584926 & Prob. $\mathrm{F}(6,54)$ & \multicolumn{2}{|l|}{0.740775} \\
\hline Log likelihood ratio & 3.966927 & Prob. Chi-Square(6) & \multicolumn{2}{|l|}{0.681152} \\
\hline \multicolumn{5}{|l|}{ Test Equation: } \\
\hline \multicolumn{5}{|c|}{$\begin{array}{l}\text { Dependent Variable: DIF_LN_DCPW } \\
\text { Method: Least Squares } \\
\text { Date: 03/18/08 Time: 12:02 } \\
\text { Sample: 1991Q3 2005Q3 } \\
\text { Included observations: } 57\end{array}$} \\
\hline Variable & Coefficient & Std. Error & t-Statistic & Prob. \\
\hline $\mathrm{C}$ & 0.039432 & 0.004117 & 9.577732 & 0.0000 \\
\hline DIF_LN_NFAW & -0.074588 & 0.033524 & -2.224940 & 0.0303 \\
\hline DIF_DCGW & $-1.51 \mathrm{E}-06$ & $7.11 \mathrm{E}-07$ & -2.125990 & 0.0381 \\
\hline R-squared & 0.147348 & Mean dependent var. & 0.033234 & \\
\hline Adjusted R-squared & 0.115768 & S.D. dependent var. & 0.028379 & \\
\hline S.E. of regression & 0.026686 & Akaike info criterion & -4.358159 & \\
\hline Sum squared resid. & 0.038456 & Schwarz criterion & -4.250630 & \\
\hline Log likelihood & 127.2075 & F-statistic & 4.665914 & \\
\hline Durbin-Watson stat. & 1.900583 & Prob. (F-statistic) & 0.013516 & \\
\hline
\end{tabular}

